melalui kontemplasi dan sikap wu wei (sikap yang seimbang antara yang baik dan buruk) dalam berbagai situasi dan kondisi di dunia ini.

Tulisan yang padat dari sisi substansi ini sangat menarik untuk dibaca bagi kita semua terutama yang peduli terhadap krisis kemanusiaan di abad millennium ketiga. Dalam tulisan tersebut muncul juga pandangan tentang manusia yang sangat teoretis, sehingga menyulitkan para pembaca non filsafat untuk memaknainya. Agaknya krisis kemanusiaan dipahami oleh para penulisnya sebagai korupsi kemanusiaan yang berada di tengah masyarakat. Penelanjangan korupsi kemanusiaan di tengah masyarakat menyadarkan kita bahwa kita tetap pada jalur etika dan relativisme moral, agar kita tidak ditandai nantinya oleh generasi berikutnya sebagai manusia penuh korupsi.

Irmayanti M. Budianto

Pengajar FIB UI, Departemen Kewilayahan

\title{
Satu Lagi Kritik Atas Dominasi HAM Barat
}

Chandra Muzaffar (dkk.) Human's Wrong: Rekor Buruk Dominasi Barat atas HAM. Diterjemahkan oleh. Anam Masrur Ba`ali, (Yogyakarta: Pilar Media, 2007), CDLX Halaman.

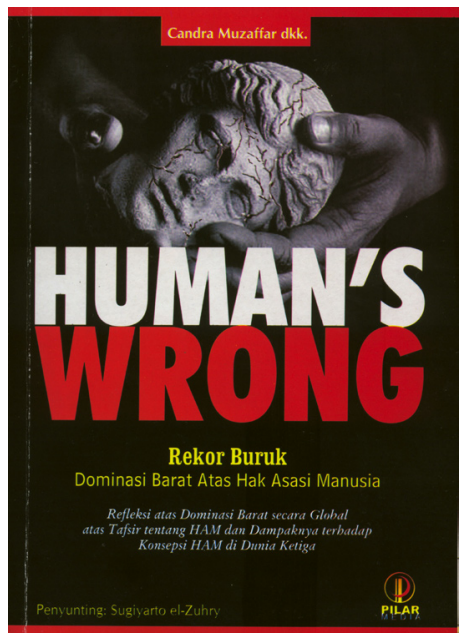

Chandra Muzaffar adalah Direktur Just Worlds Trust dan Peneliti Senior pada Science University of Malaysia. Ia juga menjadi Presiden pendiri dari organisasi nonpemerintah yang bernama Aliran Kesadaran Negara. Menulis banyak buku dan artikel ilmiah di berbagai jurnal nasional dan internasional. Dalam buku ini dia menjadi editor dan sekaligus penggagas konferensi tentang HAM yang hasilnya menjadi buku dengan judul di atas.

Buku ini merupakan kumpulan karangan (proceding) hasil Konfrensi Internasional HAM yang bertema Rethinking Human Rights yang diselenggarakan oleh Just World's Trust pada bulan Desember 1994 di Malaysia. Konfrensi itu diikuti oleh 60 pakar HAM dari berbagai negara, termasuk dari Cina, Jepang, Inggris dan Amerika Serikat. Akan tetapi oleh editornya telah ditambahkan beberapa artikel berkenaan dengan perkembangan HAM sekitar awal tahun 2000-an. Buku ini terdiri dari 4 bagian. Bagian 1 tentang HAM: Timur dan Barat yang terdiri atas 6 artikel. Bagian 2 tentang Kritik Dimensi HAM yang terdiri atas 7 artikel. Bagian 3 tentang Dampak HAM bagi Dunia Ketiga, terdiri atas 7 artikel. Bagian 4 tentang HAM: Sebagai alternatif untuk Masa Depan, terdiri atas 5 artikel. 
Judul Aslinya adalah Human`s Wrong yang kemudian ada tambahan subjudul: Rekor Buruk Dominasi Barat atas HAM. Selain itu untuk menarik perhatian pembaca oleh penerbit di Indonesia kemudian mungkin ditambahkan lagi dengan subjudul tambahan: Refleksi atas Dominasi Barat secara Global atas Tafsir tentang HAM dan Dampaknya terhadap Konsepsi HAM di Dunia Ketiga. Dari judul dan subjudul yang diterakan di sampul depan telah menyiratkan tentang maksud dan isi buku itu, yakni merupakan suatu kritik terhadap dominasi HAM Eropa dan AS yang dipaksakan kepada negara lain, tanpa memperhatikan adanya pelanggaran HAM yang dilakukan oleh mereka, baik di negara mereka sendiri maupun di luar negaranya.

Seperti diungkapkan dalam pengantar penerbit bahwa di tengah-tengah euphoria supremasi HAM dan demokrasi di era pasca PD II dan Perang Dingin, ternyata banyak pelanggaran besar-besaran HAM dalam sejarah umat manusia, yang terjadi justru di pusat dominasi kekuasaan Barat itu sendiri (hlm. iii). Secara historis dapat diurut, dimulai dari penghapusan barbarik atas suku-suku asli pedalaman di tiga benua yang kemudian diikuti oleh perbudakan, hingga terjadinya berbagai perang, sampai perang melawan terorisme. Realitas itu diungkapkan oleh banyak penulis dalam buku itu, sebagai alasan bahwa dominasi dan kendali Barat masih terjadi sampai hari ini dalam berbagai bidang kehidupan (hlm. iv).

Oleh editornya (Chandra Muzaffar) dalam kata pengantar dikatakan bahwa latar belakang diadakannya konferensi itu adalah untuk meninjau dan merefleksi ulang gagasan HAM serta praktek yang dijalankan. Konferensi itu setidaknya dapat memberikan alternatif pendekatan yang relevan terhadap pola dominasi HAM (hlm. vii). Menurutnya, evaluasi ini penting mengingat pemahaman tentang HAM ternyata masih dipertanyakan, bukan saja oleh komunitas Barat, tetapi juga oleh komunitas non-Barat. Dominasi dan Isu-isu HAM yang dilontarkan pihak Barat perlu dipertanyakan kembali. Penulispenulis dalam buku menunjukkan betapa dominasi dan kendali Barat sampai hari ini semakin canggih, bahkan memberikan dampak negatif kepada atmosfir kemasyarakatan di negara dunia ketiga. Oleh sebab itu, wajar kalau kemudian kritik terhadap dominasi HAM Barat diberi label Human Wrong. Artikel dalam buku ini mengelaborasi dan menganalisis kekeliruan yang dilakukan oleh pihak Barat dalam masalah HAM (hlm. ix).

Sebagai editor, dia juga memberikan alasan bahwa walaupun kekuasan formal kolonialisme telah berakhir, akan tetapi dominasi Barat masih tetap ada yang bergerak dalam bentuk lain. Kritik dan evaluasi ini semakin penting lantaran kekuatan ekonomi Barat telah memberikan dampak buruk bagi banyak masyarakat di kawasan Asia dan Afrika. Apalagi sangat kecil perhatian yang diberikan bagi wacana HAM kontemporer berkaitan dengan dominasi global Barat sebagai sebuah sebab utama atas terpinggirkannya martabat kemanusian. Alasannya menjadi jelas sebab siapapun yang mendominai pusat kekuasaan di Barat tidak menghendaki masyarakat lain untuk menemukan fakta keburukan mereka. Sebaliknya malah mereka yang mengagendakan dan membentuk opini HAM terbaik dalam kesadaran banyak masyarakat. 
Oleh sebab itu, artikel dalam buku ini juga mengungkapkan kegelisahan dari beberapa penulisnya terhadap kekeliruan konsep Barat tentang HAM, yang tidak memperhatikan hak sipil, politik, ekonomi, sosial, dan budaya di banyak kawasan dunia (hlm. 1-6).

Dalam buku ini kita juga dapat membaca tulisan dari Mahatir Mohammad, yang pada waktu itu masih menjabat sebagai Perdana Menteri Malaysia. Sebagai tokoh pembicara pertama, Mahatir mengatakan bahwa kondisi HAM sekarang merupakan suatu realitas sekaligus ironi. Di satu pihak pemerintah non-Barat terancam karena pelanggaran kecil akan HAM, di pihak lain (ketika kepentingan Barat tidak terancam), mereka dipersiapkan untuk melakukan pelanggaran HAM yang brutal di depan mata kita. Oleh sebab itu, HAM perlu didiskusikan dan bahkan didefiniskan ulang yang untuk kemudian ditegakkan secara proporsional. Ditandaskan olehnya, bahwa tidak ada seorangpun yang mempunyai hak untuk mengklaim mempunyai otoritas untuk memonopoli pemahaman atas HAM. Walau harus diakui juga bahwa orang Asia bukanlan contoh pelaku terbaik HAM. Mereka juga pernah melakukan kesalahan di masa lalu dan sampai hari ini. Tetapi tentu tidak sedahsyat yang digambarkan media Barat. Atas dasar itu, sudah sepantasnya orang Asia juga dapat memberikan saran dan masukan terhadap nilai-nilai yang dapat membantu memecahkan persoalan HAM (hlm. 11-21).

Dalam kaitan HAM dan Moralitas Global dikatakan oleh salah seorang penulisnya, bahwa piagam HAM sekarang ini tidak memuat beberapa solusi yang mungkin terhadap persoalan ketidakadilan global atau membentuk cetak biru sebuah Tatanan Dunia yang Adil (Just World Order). Menurut penulisnya lagi bahwa problem mendasar dari gagasan HAM adalah terletak pada kesalahpahaman akan sifat dasar politik manusia (hlm. 27-28).

Di bagian lain, seorang penulis mengungkapkan dampak emansipatif dari wacana HAM. Dikatakan, walaupun HAM telah lebih dari 30 tahun, akan tetapi tidak menjadi efektif. Oleh sebab itu, sebaiknya DUHAM diganti dengan Deklarasi Universal tentang Kewajiban Asasi Manusia (DUKAM). Wacana Barat tentang HAM bekerja atas batasan kabur berkaitan dengan ekspresi diri dan kepemilikan yang tidak disertai rasa tanggungjawab terhadap prikehidupan dan kebutuhan masyarakat lain. Kritik lainnya adalah bahwa HAM sering digunakan sebagai instrumen dalam kebijakan luar negeri dan bukan sebagai upaya koreksi terhadap kelemahan dalam negeri. Kondisi ini menunjukkan adanya tendensi distorsi secara khusus dalam kontroversi sekarang ini, yaitu tentang peniadaan perhatian akan HAM di dalam interaksi ekonomi di antara Barat dan negara-negara di Asia. Sumber dari distorsi itu adalah ketidakbersalahan Barat yang melupakan peran historisnya di wilayah tersebut (hlm. 41,48).

Tulisan lainnya lebih menitikberatkan pada realitas historis kesalahankesalahan pihak Barat dalam kebijakan politik dan ekonominya di luar kawasan mereka. Di antaranya ditulis oleh Fan Yew Teng dari Cina yang mengungkapkan Kejahatan dan Rapor Merah Barat atas HAM. Pada halaman terakhirnya dia mengkritik Samuel Huntington yang menulis tentang 
Benturan Peradaban (clash of civilization) yang menurutnya, bukan memberikan pencerahan dan perdamaian, malah memberikan peluang dan anjuran untuk perdagangan senjata. Lebih tegas dikatakan bahwa Huntington tidak lebih dari seorang sales senjata dan bukan cendikiawan politik (hlm. 53-96).

Kritik yang sama juga dikemukakan oleh David G. du Bois dari AS sendiri yang mengungkapkan Rasisme di Negara Barat yang masih tetap bertahan dan dipertahankan. Pada akhir tulisannya dikatakan, bahwa karena penduduk Barat tetap diam membisu terhadap pelanggaran HAM yang mereka lakukan terhadap lima per enam penduduk dunia (hlm. 96-106). Penulis lain, Erskine Childers, mantan Penasehat Senior PBB mengkritik tentang peran PBB dalam kaitannya dengan pelanggaran HAM yang dilakukan oleh pihak Barat. Hal itu menurutnya merupakan kegagalan PBB sebab PBB hanya berdiam saja ketika AS dan sekutu Baratnya melakukan suatu intervensi kemanusian atas nama PBB. Dengan kata lain, itu merupakan suatu tindakan penyalahgunaan piagam PBB yang harus diberi sanksi. Akan tetapi PBB dan para anggotanya dimandulkan oleh dominasi negara Barat. Kita semua telah diprogram dan dikondisikan untuk lebih baik menyerah di depan raksasa pemangsa. Oleh sebab itu, anjurannya adalah dibutuhkan suara Selatan dan Timur yang lebih vokal (hlm. 111-119, 125).

Kekuasaan pihak Barat dimanifestasikan melalui rezim sain dan teknologi, selain rezim perekonomiannya. Itu semua telah memberikan Barat alat yang sangat berbahaya, di samping sangat efektif untuk mencabut secara mutlak hak asasi manusia penduduk dunia. Hal itu disampaikan oleh Claude Alvares, seorang Editor majalah dari India (hlm.137). Konsekwensi sosial dari sain dan teknologi Barat termasuk dalam pelanggaran HAM sebab akan mengancam sumber daya alam masyarakat lain (hlm.155). Hal lain yang menjadi perhatian, adalah HAKI yang merupakan instrumen baru di dalam kekuasaan global negara Barat, padahal sesungguhnya pengetahuan yang dilindungi itu bersumber dari budaya non-Barat (hlm. 162). Implikasi dari suatu pandangan dunia yang menganggap kepemilikan intelektual terbatas hanya untuk satu kelas masyarakat menjadi alasan untuk mengklaim semua produk tenaga kerja intelektual bangsa lain sebagai milik pribadinya, sama halnya sewaktu mereka mengambil dari negara-negara lain di dunia ketiga. Hak milik intelektual dan hak paten atas kehidupan merupakan ekspresi puncak dari hasrat untuk mengontrol semua yang hidup dan bebas, persis seperti zaman kolonialisme mereka dulu (hlm. 165).

Kritik lain dilontarkan oleh Jeremi Corbyn, Anggota DPR dari Partai Buruh Inggris yang mengatakan bahwa usaha negara Utara (Barat) untuk mendominasi agenda HAM tidak hanya bersifat hipokrit, tetapi juga curang. Apalagi hanya sedikit usaha untuk mencari tahu apakah suatu masyarakat di suatu negara benar-benar menginginkan bentuk demokrasi yang dipromosikan oleh AS. Ditekankan olehnya, bahwa negara Utara perlu mengetahui bahwa kebudayaan Utara bukanlah satu-satunya model peradaban, sehingga negara di Selatan harus meniru, tetapi yang dibutuhkan adalah dialog terbuka. Sanksi dan embargo semestinya bersifat memberikan 
rasa aman dan ditujukan kepada orang yang bersalah dan bukan terhadap rakyat secara keseluruhan. Selain itu, wacana HAM akan gagal apabila HAM dipandang sebagai pemberian yang ditetapkan melalui konvensi dan deklarasi yang ditentukan oleh negara Utara. Hal lain yang disingung adalah jika kapitalisme Barat itu merasa superior, mengapa kapitalisme Barat merasa sangat terancam selama Perang Dingin atau selama negara Selatan dan nonBarat melakukan alternatif dalam pembangunannya. Suatu pertanyaan tajam, yang perlu untuk dielaborasi lebih lanjut dalam sistem perekonomian dunia (hlm 196-197).

Penulis lain juga mengkiritk pemikiran Samuel Huntington dalam karya lamanya yang berjudul Political Order in Changing Societies tahun 1964. Pada buku itu Huntington menjelaskan perlunya pemimpin yang otoriter dalam melaksanakan pembangunan yang menjadi proyek demokratisasi. Buku itu kemudian menjadi buku pegangan bagi generasi baru para pejabat di Departemen Dalam Negeri, Lembaga Bantuan Pembangunan Internaional (USAID), dan Bank Dunia. dikatakan oleh pengkritiknya bahwa di tengah masyarakat Dunia Ketiga yang kacau balau, seorang profesor politik Harvard beragumentasi dan berharap pada sebuah pemerintahan demokratis, padahal di sana tidak ditemukan suatu tradisi demokratis. Hal itu dikatakan oleh Walden Bello, Direktur Eksektif dari sebuah LSM (hlm. 265).

Berbagai realita historis telah dikemukakan oleh para penulis dalam buku itu tentang ketidakadilan dan dominasi HAM Barat. Pada kesimpulannya dikatakan bahwa berbagai peristiwa itu secara tidak langsung telah mengangkat suara bahwa HAM universal harus dipusatkan pada seting rumah sendiri terlebih dulu, sebelum dipaksakan kepada pihak lain. Konsepsi dominasi HAM universal adalah suatu yang penuh dengan ketidakkonsistenan dalam praksis dan dalam keterbatasan penerapan (hlm. 385). Bahkan ditambahkan oleh Anwar Ibrahim yang pada waktu itu menjabat sebagai wakil Perdana Mentri Malaysia, bahwa perlindungan HAM merupakan persoalan moral mendasar yang harus menjadi komitmen bersama dan seyogyanya tidak untuk digunakan sebagai suatu alat kebijakan luar negeri dari suatu negara tertentu atau sebagai kuda Troya untuk menyembunyikan kepentingan tertentu (hlm. 430).

Dalam rekomendasi pada kesimpulan buku itu dikatakan oleh Editornya, bahwa karena adanya kekurangan di dalam karakater HAM Barat, maka perlu pihak lain mencoba mengembangkan visi mertabat manusia yang lebih adil, lebih holistik, dan lebih universal (hlm. 441). Oleh sebab itu, tujuan konferensi dan penerbitan buku ini adalah untuk menuju pada pemahaman yang lebih baik terhadap masalah HAM serta mengembangkan sebuah karakter lain yang didasarkan atas spiritual, keadilan, dan kemerdekaan untuk menuju Tatanan Dunia yang Adil, sesuai dengan konsepsi penggagasnya, yakni Just World Order. Dengan kata lain, perlunya kembali merumuskan pengertian HAM yang bermartabat (Human Dignity) (hlm. 450,452).

Walaupun telah banyak buku yang membahas tentang kritik HAM, akan tetapi dengan adanya buku ini, para peminat HAM dan demokrasi akan 
mendapat suguhan tambahan yang mungkin belum disentuh oleh pihak lain, yakni penggambaran realitas historis dan praktek-praktek kekerasan yang dilakukan oleh pihak Barat di kawasan non-Barat. Hal ini sangat ironis dan terbalik dari gagasan HAM yang diperjuangkan oleh pihak Barat sendiri. Buku ini layak dibaca semua pihak yang tertarik pada isu dan masalah penegakan HAM dan demokrasi. Buku ini juga menawarkan pandangan alternatif tentang HAM dari perspektif non-Barat.

Zeffry Alkatiri Pengajar di Departemen Sejarah -Program Studi Rusia FIB UI Zeffry_al@yahoo.com 